\title{
INVESTIGATION OF Botrytis cinerea RISK FORECASTING MODEL OF STRAWBERRY IN LITHUANIA
} \author{
and Skaidrè Suproniene் $\dot{~}^{\star *}$ \\ * Institute of Horticulture, Lithuania Research Centre for Agriculture and Forestry, \\ 30 Kauno Str., Babtai, Kaunas distr., LT-54333, LITHUANIA; \\ n.rasiukeviciute@Isdi.It \\ ** Institute of Agriculture, Lithuania Research Centre for Agriculture and Forestry, \\ 1 Instituto av., Akademija, Kedainiai distr., LT-58344, LITHUANIA
}

Neringa Rasiukevičiūtè*, Alma Valiuškaitè*, Elena Survilienè-Radzevičè*,

\begin{abstract}
Grey mould, caused by Botrytis cinerea Pers.:Fr. is one of the most important strawberry diseases in Lithuania, like in other countries, where strawberries are grown. The efficiency of different disease management systems were analyzed at the Institute of Horticulture in 2010-2011. The B. cinerea risk probability at various regions of Lithuania was analyzed according to iMETOS $尺$ sm grey mould risk forecasting model. Strawberry grey mould risk forecasting model indicates the risk of infection periods on the basis of the interaction between air temperature and leaf wetness duration. The model calculates how favourable is the period for the risk of infection. In periods where the risk is consistent (more than three days), higher than 60 points, a spray against grey mould should be applied. iMETOS $®$ sm grey mould risk forecasting model gives the opportunity to optimize the usage of fungicides and reduce the number of applications and allows more efficient, ecologically and economically accepted control of strawberries grey mould.
\end{abstract}

Key words: grey mould risk, iMETOS $囚$ sm, leaf wetness, air temperature.

Botrytis cinerea can seriously reduce strawberry yield and post-harvest quality (Miličevič et al., 2006; Shtienberg, 2007). Grey mould infects leaves, fruits, flowers, petioles, stems and often starts early as strawberry blossom blight. Flower infections are the main reason for latent infections leading to damages during the storage. Mostly pathogen remains invisible until ripening and then may cause fruit rot before or after harvest (Blanco et al., 2006; Williamson, 2007). B. cinerea cause the highest strawberry fruit and yield lost, it can be from $15 \%$ up to $50 \%$ (Blanco et al., 2006).

Conventionally grey mould is controlled by protecting flowers from infection by applications of fungicides every 7-14 days during strawberry flowering at 61-69 BBCH growth stages (Miličevič et al., 2006; Shtienberg, 2007). During the growing season in horticulture significant amounts of pesticides are consumed to control diseases. A large part of fungicides are used for preventative applications. Using disease forecasting models, applications of fungicides are made only when it is necessary (Shtienberg and Elad, 1997; Shtienberg, 2007).

The grey mould infection risk of the strawberry flowers mostly depends on temperature and humidity. Bulger et al. (1987) found resonance correlations for leaves wetness peri- ods and temperature. If wetness periods last for 32 hours at $20{ }^{\circ} \mathrm{C}$, the probability of grey mould infection is $60 \%$. A forecasting model was used to calculate how favourable the periods are for the risk of infection for B. cinerea (Bulger et al., 1987).

Research on the efficiency of forecasting models for pests and diseases in horticultural plants under Lithuanian climate conditions using internet forecasting system iMETOS®sm (Pessl Instruments, Austria) was started at the Institute of Horticulture in 2007 (Valiuškaitè et al., 2008; Raudonis and Valiuškaite, 2009). These studies were conducted under the long-term project "Establishment of warning models of horticultural plant diseases and pests and its implementation in Lithuania using warning equipment". One of the goals of this research was to investigate the Botrytis cinerea forecasting model for strawberries in Lithuanian conditions.

The two-year studies were carried out at the Institute of Horticulture in 2010-2011. Field trials were carried out in strawberries cv. 'Elkat' plantation. The control of strawberry grey mould was realised by different disease management systems: conventional plant protection system (conventional system) and iMETOS®sm B. cinerea risk forecasting model (forecasting model). For control of grey mould selected fungicide Switch 62.5 WG (a.i. Ciprodinil + 
Fludioksonil $375+250 \mathrm{~g} / \mathrm{kg}$ ), rate $1.0 \mathrm{~kg} \mathrm{ha}^{-1}$. In order to evaluate the risk of infection records were compared of iMETOS®sm weather stations located in different agroclimatic regions of Lithuania: the first one was in the Central (Kaunas) region, the second one in the South (Alytus), and third one - in the North (Pasvalys) region.

iMETOS $® \mathrm{sm}$ B. cinerea risk forecasting model records leaf wetness, rainfall, air temperature and other parameters, also calculates the risk of infection every hour, the records are received on the internet http://www.fieldclimate.com/ (Valiuškaitè et al., 2008; Raudonis and Valiuškaitè, 2009). Strawberry iMETOS®sm $B$. cinerea risk forecasting model indicates the risk of infection periods on the basis of interaction between air temperature and duration of leaf wetness. Grey mould risk forecasting model calculates how favourable are periods for the risk of infection. According to the manufacturer guidelines, if iMETOS®sm grey mould risk forecasting model shows the infection risk periods more than $60 \%$ probability (which lasts longer than three days), a spray against grey mould should be applied.

Analysis of records of iMETOS®sm grey mould risk forecasting model in the Central region showed dissimilar $B$. cinerea occurrence in both years of investigation (Fig. 1). The risk of infection was greater than $60 \%$ and lasted for 15 days in May and 14 days in June of 2010. Meanwhile, in 2011 there was no risk of infection in May and only two days in June (Fig. 1). Therefore, observing meteorological conditions in plots treated according to the forecasting model only two applications were performed in 2010 while by the conventional system four applications were performed in both years of investigation. Comparison of different disease management system advisable experiments showed that the first and the second application time in 2010 coincided, but other application times differed. The first application under the conventional system in 2010 was performed on May 16 and under the forecasting model on May 15. At that time strawberries were at $61-65 \mathrm{BBCH}$ growth stages. The second application depending on the conventional system was on May 23 and by the forecasting model on May 21 of 2010. Other application times in 2010 differed, since the risk of infection was lower than $60 \%$ or the risk reached $60 \%$ at the strawberry harvesting time, when application is impossible. Weather conditions during strawberry flowering in 2011 were exceptional comparing to year 2010. The year was dry and there was no need of us-

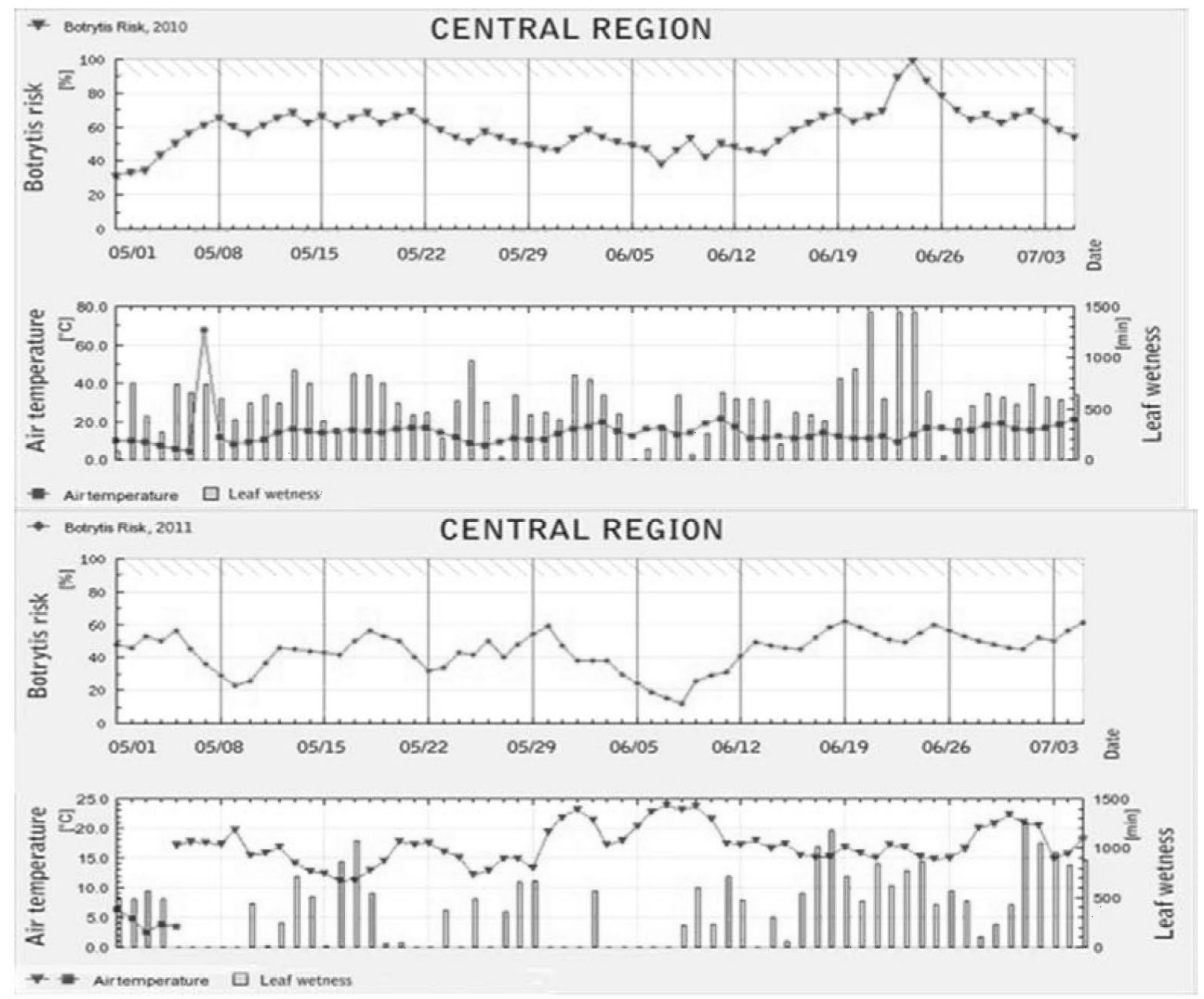

Fig. 1. Strawberry grey mould risk dynamics according to iMETOS®sm forecasting model. Central region, $2010-2011$. 
Table 1

INFLUENCE OF DISEASE MANAGEMENT SYSTEMS IN CENTRAL REGION OF LITHUANIA, 2010-2011

\begin{tabular}{|c|c|c|c|c|c|c|}
\hline \multirow{3}{*}{$\begin{array}{c}\text { Disease } \\
\text { management } \\
\text { system }\end{array}$} & \multicolumn{4}{|c|}{ Strawberry fruits, $\% *$} & \multirow{2}{*}{\multicolumn{2}{|c|}{$\begin{array}{c}\text { Efficiency of sys- } \\
\text { tems, } \%\end{array}$}} \\
\hline & healthy & rotten & healthy & rotten & & \\
\hline & \multicolumn{2}{|c|}{2010} & \multicolumn{2}{|c|}{2011} & 2010 & 2011 \\
\hline Unsprayed & 91,83 & 8.17 & 93.85 & 6.15 & - & - \\
\hline $\begin{array}{l}\text { Conventional plant } \\
\text { protection system }\end{array}$ & 97.50 & 2.5 & 98.06 & 1.94 & 69.40 & 68.46 \\
\hline $\begin{array}{l}\text { iMETOS } ® s m \text { risk } \\
\text { forecasting model }\end{array}$ & 98.00 & 2,0 & 97.80 & 2.20 & 75.52 & 64.23 \\
\hline
\end{tabular}

* sample 1000 fruit

ing fungicides, because the risk of infection was minimal. The application time in 2011 according to the conventional system was similar as in 2010.

Comparison of different protection systems showed that both disease management systems reduced the spread of grey mould in strawberries (Table 1). 8.17 and $6.15 \%$ of strawberries were rotten in unsprayed plots in 2010 and
2011, respectively. According to the conventional plant protection system, in 2010 there were $2.5 \%$ rotten strawberries and in $2011-1.94 \%$. Similar results were in plots treated according to the forecasting model -2.0 (2010) and $2.20 \%$ (2011).

By evaluating and comparing the records under the forecasting model in different agro-climatic regions of Lithuania diverse results were obtained (Fig. 2). According to the data of the iMETOS $®$ sm grey mould risk forecasting model, the risk of infection was lower than $60 \%$ and there was no need for use of fungicides in South and North regions in May 2010-2011 and in North region in June 2010. Whereas the risk of infection was greater than $60 \%$ in South and North region for five days in June of 2010 and in South region for three days in June of 2011. The risk of infection in both regions was unfavourable or minimal, thus there was no need to use fungicides.

The iMETOS®sm grey mould risk forecasting model analysis shows that disease forecasting allows applying fungicides precisely then it is needed, which leads to environmentally friendly plant protection. Spraying fungicides according to the conventional plant protection system was

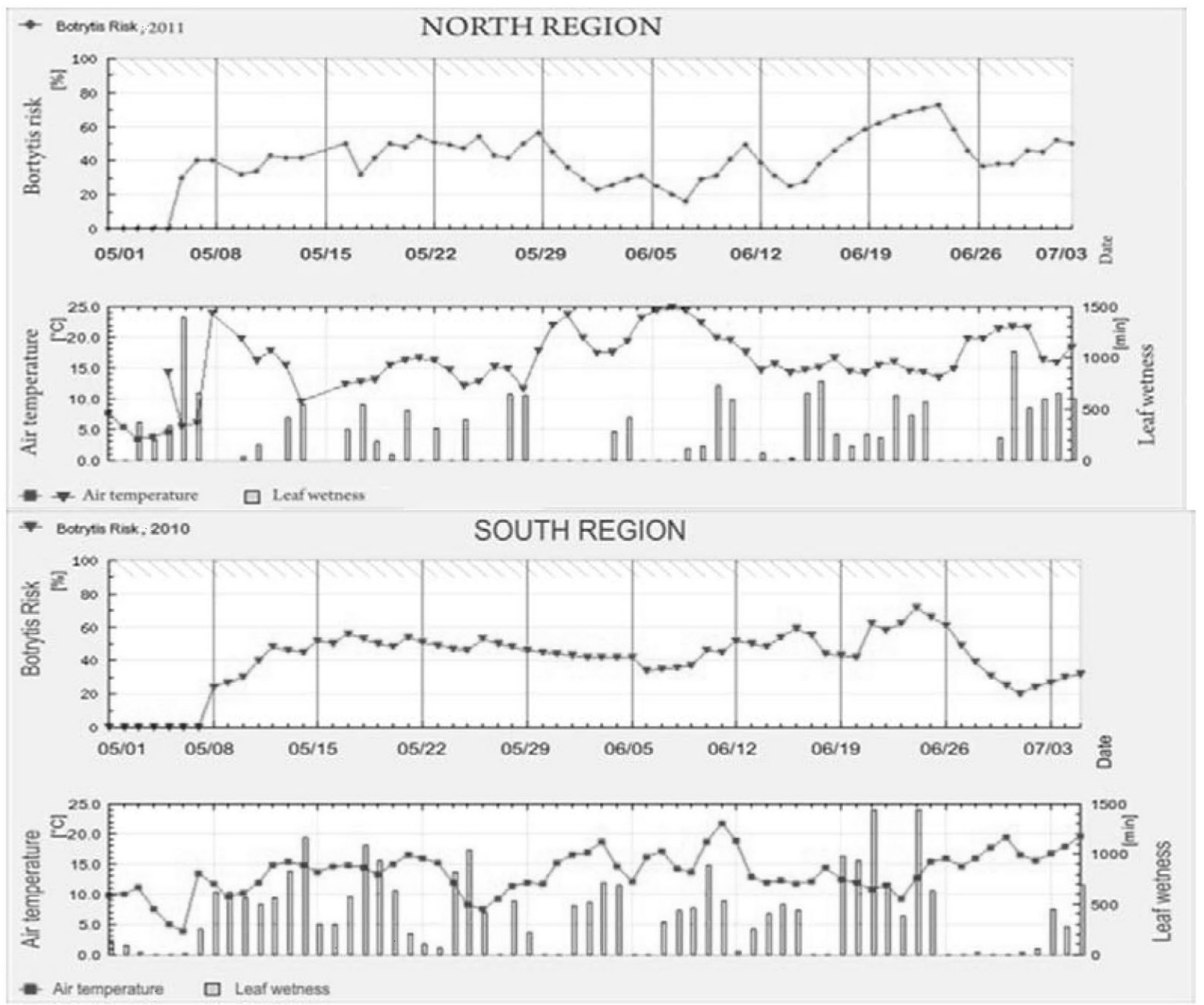

Fig. 2. Strawberry grey mould risk dynamic according to iMETOS®sm forecasting model. North (2011) and South (2010) regions. 
effective, on average, $68.93 \%$, and spraying according to the forecasting model $-68.38 \%$, compared with unsprayed strawberries.

The research was supported by the Ministry of Agriculture and continued in the long-term research programme "Harmful organisms in agro and forest ecosystems (KOMAS)" implemented by Lithuanian Research Centre for Agriculture and Forestry.

\section{REFERENCES}

Blanco, C., Santos, B., Romero, F. (2006). Relationship between concentrations of Botrytis cinerea conidia in air, environmental conditions, and the incidence of grey mould in strawberry flowers and fruits. Eur. J. Plant Pathol., 114 (4), 415-425.

Bulger, M. A., Ellis, M. A., Madden, L. V. (1987). Influence of temperature and wetness duration on infection of flowers by Botrytis cinerea and dis- ease incidence of fruit originating from infected flowers. Phytopathology, 77 (8), 1225-1230

Miličevič, T., Ivič, D., Cvjetkovič, B., Duralija, B. (2006). Possibilities of strawberry integrated disease management in different cultivation systems. Agricult. Conspectus Sci., 71 (4), 129-134.

Raudonis, L., Valiuškaitè, A. (2009). Integrated approach of apple scab management using iMETOS warning system. Sodininkystè ir Daržininkystè, 28 (3), 181-191.

Shtienberg, D. (2007). Rational management of Botrytis-incited diseases: Integration of control measures and use of warning systems. In: Botrytis: Biology, Pathology and Control (pp. 335-347). Springer: The Netherlands.

Shtienberg, D., Elad, Y. (1997). Incorporation of weather forecasting in integrated, biological-chemical management of Botrytis cinerea. Phytopathology, 87 (3), 332-340.

Valiuškaitè, A., Raudonis, L., Survilienè, E. (2008). Control of grey mould and white leaf spot in strawberry. Agriculture, 95 (3), 221-226.

Williamson, B., Tudzynski, B., Tudzynski, P., Van Kan, J. A. L. (2007) Botrytis cinerea: The cause of grey mould disease. Mol. Plant Pathol., 8 (5), 561-580.

Received 29 November 2012

\section{Botrytis cinerea RISKA PROGNOZĒŠANAS MODEL̨A ZEMENĒM IZPĒTE LIETUVĀ}

Pelēkā puve, ko izraisa Botrytis cinerea Pers: Fr., ir viena no svarīgākajām zemeṇu slimībām gan Lietuvā, gan arī citās valstīs, kur zemenes tiek audzētas. Pētījumi par prognozēšanas modeḷu efektivitāti dārzkopības augu kaitēkḷiem un slimībām Lietuvas klimatiskajos apstākḷos, izmantojot interneta prognozēšanas sistēmu iMETOS @ cm (Pessl instrumenti, Austrija), tika uzsākti Dārzkopības institūtā 2007. gadā. Šajā pētîjumā veikti novērojumi par zemeṇu iMETOS ® sm pelēkās puves riska prognozēšanas modeliiem 2010.-2011. gadā. Darba mērkis bija analizēt $B$. cinerea slimības riska iespējamību dažādos agroklimatiskajos apstākḷos dažādos Lietuvas reǵionos. Zemeņu pelēkās puves riska prognozēšanas modelis norāda inficēšanās risku, pamatojoties uz mijiedarbību starp gaisa temperatūru un lapu samitrinājuma ilgumu. Modelis aprēkina, kāds inficēšanās risks ir konkrētajā periodā. Periodos, kad risks ir konsekventi (vairāk nekā trīs dienas) lielāks nekā 60 punkti, pret pelēko puvi jāpielieto smidzinājumi. iMETOS ${ }^{\circledR} \mathrm{cm}$ pelēkās puves riska prognozēěanas modelis dod iespēju optimizēt fungicīdu izmantošanu un samazināt pielietojumu skaitu, tādējādi ļaujot daudz efektīvāk, videi draudzīgāk un ekonomiski pamatotāk kontrolēt zemenu pelēko puvi. 